\title{
Palaeoenvironmental changes in the Transylvanian Basin during the Early Miocene revealed by the foraminifera assemblages
}

\author{
Szabolcs-Flavius SZÉKELY ${ }^{1, *}$, Claudia BELDEAN ${ }^{1}$, Raluca BINDIU ${ }^{1}$, Sorin FILIPESCU ${ }^{1}$ \\ and Emanoil SĂSĂRAN ${ }^{1}$ \\ 1 Babeş-Bolyai University, Faculty of Biology and Geology, Department of Geology, 1 Mihail Kogălniceanu Street, 400084 \\ Cluj-Napoca, Romania
}

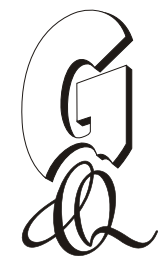

\begin{abstract}
Székely, S.-F., Beldean, C., Bindiu, R., Filipescu, S., Săsăran, E., 2016. Palaeoenvironmental changes in the Transylvanian Basin during the Early Miocene revealed by the foraminifera assemblages. Geological Quarterly, 60 (1): 167-180, doi: 10.7306/gq.1245

The evolution of the Transylvanian Basin during the Early Miocene has been reconstructed from the succession of palaeoenvironments inferred from sedimentological trends and the succession of specific foraminiferal assemblages from Lower Miocene Tihău section in the northwestern Transylvanian Basin. Planktonic foraminifera suggest a Burdigalian age and record sea level changes, climatic and productivity events. Benthic foraminifera offer data on the palaeoenvironmental evolution, with a large-scale progradational (coarsening up) sedimentary succession influenced by regional tectonics. The succession of depositional events includes: (1) transgressive coarse grained deposits with typical Mediterranean assemblages of bivalves in beach environments; (2) a glauconitic facies which can be associated with the maximum flooding surface of the transgression; (3) sedimentation continued on a narrow shelf influenced by deltas during the highstand; (4) the influence of regional tectonics and subsequent filling with turbidites associated with fan deltas.
\end{abstract}

Key words: Early Miocene, Transylvanian Basin, Central Paratethys, foraminifera, palaeoenvironments.

\section{INTRODUCTION}

The Paratethys (Laskarev, 1924), as a large epicontinental sea extending from Central Europe to Central Asia since the Oligocene, gradually transformed into an inland sea and finally into a series of giant lakes because of ongoing continental collision that shaped the Alpine-Himalayan orogenic belt (Rögl, 1998). Tectonic deformations during the Neogene caused particular evolution of Paratethyan sub-basins and a progressive isolation from the open ocean, which induced endemism of the biota. The Transylvanian Basin, one of the major basins of the Central Paratethys, preserves characteristic stratigraphic features but faces the same bio- and chronostratigraphic difficulties in correlation with the standard zones and stages. Recent attempts to improve the correlation criteria for the Miocene of the Transylvanian Basin, with implications for the Paratethyan stratigraphy, were carried out by Krézsek and Filipescu (2005) Filipescu and Silye (2008), Beldean et al. (2010), Krézsek et al (2010), Vasiliev et al. (2010), Filipescu et al. (2011), and de Leeuw et al. (2013).

One of the representative areas for the Lower Miocene is the northwestern Transylvanian Basin (Fig. 1), where diverse

* Corresponding author, e-mail: szekelyflavius@gmail.com

Received: July 17, 2015; accepted: August 20, 2015; first published online: August 24, 2015 palaeoenvironmental settings (from continental to shallow- and deep-marine - Popescu, 1975; Popescu et al., 1995; Filipescu, 2011) controlled the distribution of fossil assemblages. Due to this facies complexity and limited connections to the ocean, application of the existing biozonation (Popescu, 1975; Beldean et al., 2010) proved difficult in some cases. For this reason we decided to look more carefully into the relationship between the types of sedimentary facies and their micropalaeontological content, as clues for palaeoenvironmental reconstruction and for identification of improved correlation criteria.

The Lower Miocene sedimentary record of the Transylvanian Basin reaches up to $1000 \mathrm{~m}$ and has been preserved mainly in the flexural basin developed in front of the thrusting Pienides (Krézsek and Bally, 2006). Borehole data and regional interpretations (Dicea et al., 1980; Krézsek and Bally, 2006; Tischler et al., 2008) indicate a large-scale shallowing upward trend. Several lithostratigraphic units were described for coexisting particular sedimentary paleoenvironments (Fig. 2).

The superposition of the particular lithofacies was produced due to the initial transgression (basin formation) and subsequent regression (uplift of the Pienides; Beldean et al., 2012). The studied section from Tihău displays parts of the Lower Miocene Coruş, Chechiş, and Hida formations.

\section{MATERIAL AND METHODS}

Nineteen samples were collected from fine siliciclastic sediments from the Chechis and Hida formations (Fig. 3) near the 

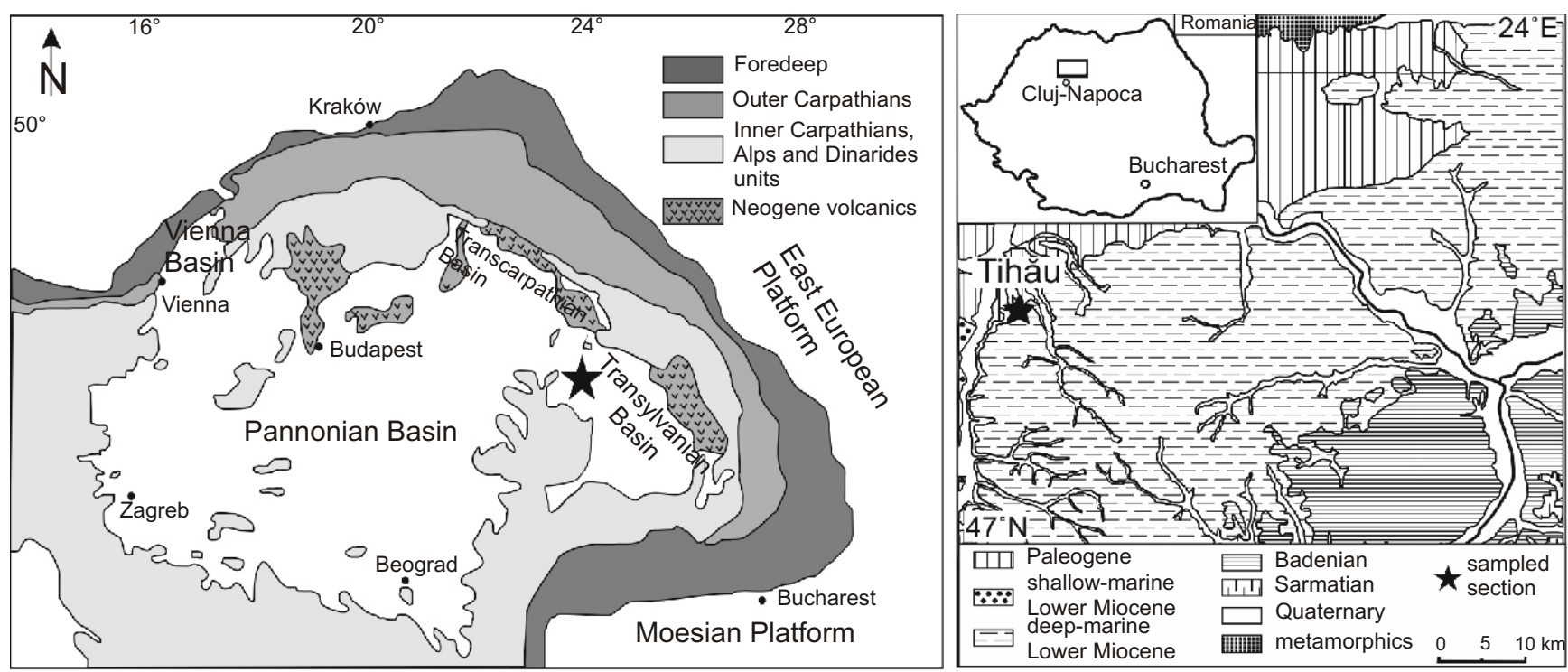

Fig. 1. Position of the studied area in the Transylvanian Basin (left) in the context of the Central Paratethys; detailed geological map (right) and location of the studied outcrop (modified after Beldean and Filipescu, 2011)

Tihău locality (Lânii Valley, Sălaj County - 47²'20.96”N, $23^{\circ} 20^{\prime} 34.32$ "E; Fig. 1). Seventeen samples were recovered from a continuous succession (Fig. 3), while two of them were collected from a lower outcrop (Fig. 3). The sedimentological interpretation relies on outcrop measurements and observations.

Standard micropalaeontological preparation methods were applied on $250 \mathrm{~g}$ of sample (boiling in tap water with one tablespoon of sodium carbonate $-\mathrm{Na}_{2} \mathrm{CO}_{3}-$ for approx. 1 hour, washing over a $63 \mu \mathrm{m}$ brass mesh sieve and drying); when necessary, the sediment was treated with $0.3 \%$ hydrogen peroxide $\left(\mathrm{H}_{2} \mathrm{O}_{2}\right)$ to further disintegrate the clay minerals. More than 300 foraminifera were picked from the $>63 \mu \mathrm{m}$ fraction. Primary identification was done under a stereomicroscope, while several specimens were examined in detail with a scanning electron microscope at the Electron Microscopy Center of the Babeş-Bolyai University. The foraminifera were identified at species-level (if possible), sorted, and counted.
Planktonic foraminifera were used to estimate the water palaeodepth by calculating the planktonic/benthic $(\mathrm{P} / \mathrm{B})$ ratios based on the relation: $P / B=100(P / P+B)$ (Murray, 1991).

Complementary data were used to reduce the possible distortions introduced by transport and redeposition (Van der Zwaan et al., 1990; Van Hinsbergen et al., 2005).

Some quantitative data were calculated for the benthic foraminiferal assemblages using the computer software PAST (Hammer et al., 2001) in order to obtain palaeoecological proxy records:

- Fisher's alpha diversity index, which remains constant regardless of the number of individuals and high values indicate high species diversity (Murray, 1991);

- Shannon index that takes into account both the number of species and the amount of individuals within species (Murray, 1991);

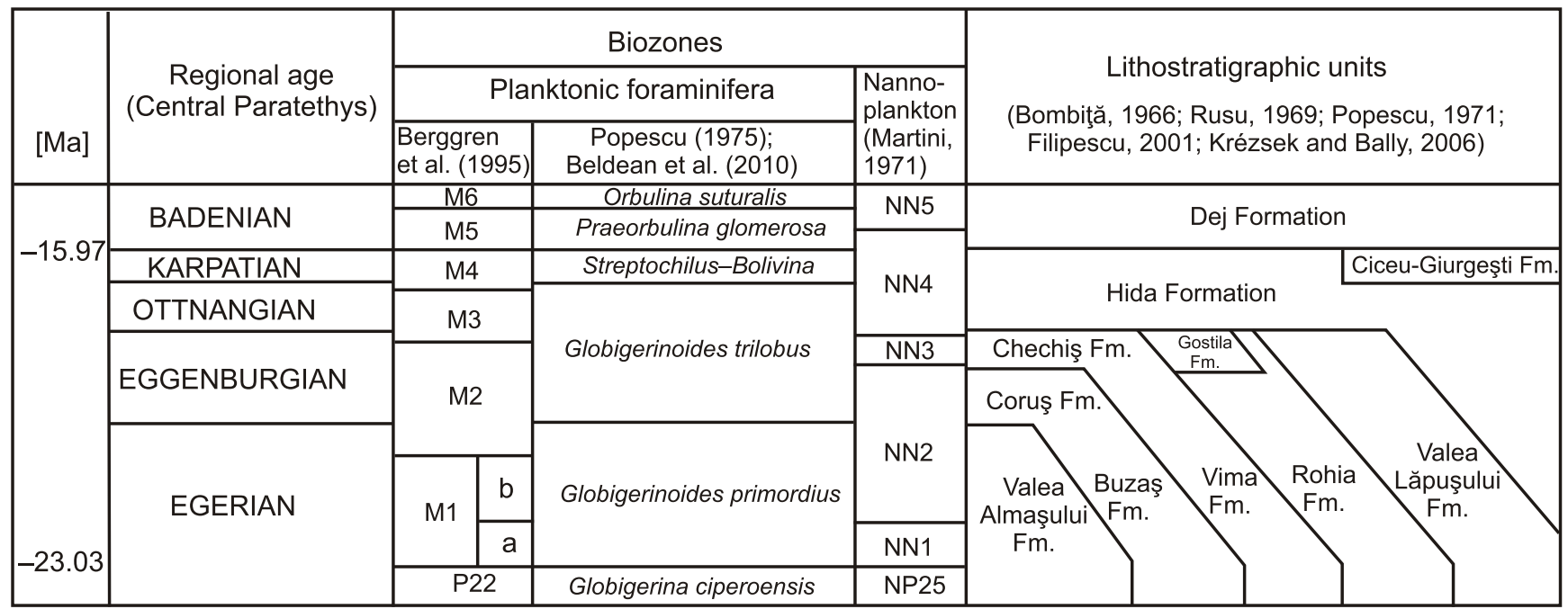

Fig. 2. The correlation between the Lower and Middle Miocene biozones based on the foraminifera and calcareous nannoplankton with the lithostratigraphic units in the Transylvanian Basin (after Beldean et al., 2012) 


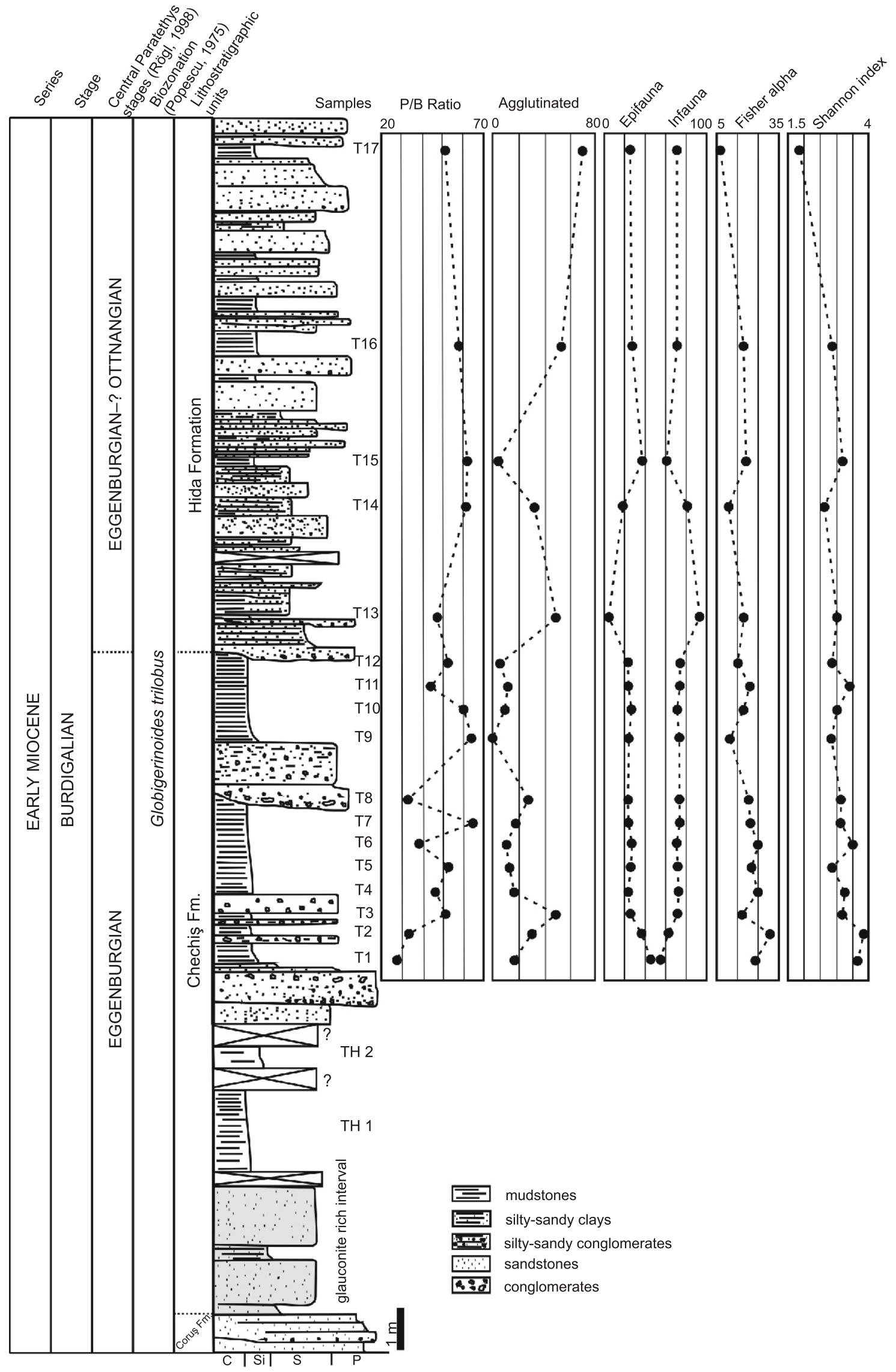

Fig. 3. Sedimentary log of the studied section, position of samples and univariate statistics such as the P/B ratio, percent of agglutinated foraminifera, percent of epifauna and infauna microhabitats, and diversity indices (Fisher alpha and Shannon indices) 
- the relative abundance of agglutinated taxa (Murray, 1991);

- the relative abundance of epifaunal (usually abundant in well-oxygenated environments) and infaunal (able to live with low oxygen contents) taxa was used to estimate bottom water oxygen (Jorissen, 1999);

- the relative abundance of most important benthic foraminifera species, genera or groups with similar palaeoecological affinities was used to characterize the palaeoenvironmental evolution.

The classification of the benthic foraminifera in epifaunal or infaunal, and as oxic, suboxic or dysoxic indicators was based on literature data and the morphology of the test (e.g., Corliss and Chen, 1988; Corliss and Fois, 1990; Sen Gupta and Machain-Castillo, 1993; Kaiho, 1994, 1999; Kouwenhoven and Van der Zwaan, 2006; Jorissen et al., 2007; Kaminski, 2012).

The palaeoclimatic significance of certain planktonic foraminifera species was deduced based on direct information from the literature (e.g., Li et al., 1992; Spezzaferri, 1994, 1995; Spezzaferri and Ćorić, 2001; Spezzaferri et al., 2002; Rögl and Spezzaferri, 2003; Bicchi et al., 2003, 2006; Pearson et al., 2006; Alegret et al., 2008).

\section{RESULTS}

\section{SEDIMENTOLOGY}

The Coruş Formation. The transgressive deposits belonging to the Coruş Formation are represented by well-sorted thick packages of sandstones alternating with centimetric/decimetric conglomerates containing shell lags with large molluscs (especially pectinidae) typical for the littoral areas (Moisescu and Popescu, 1980).

The sandstones are characterized by cross- and parallel lamination (subaqueous dunes). The transition from the sandstones belonging to the Coruş Formation to the bioclastic silty-sandy clays with glauconite (approx. $2.5 \mathrm{~m}$ thick) of the Chechiş Formation is gradational or sharp (Fig. 3). The glauconite deposits are grading upward into grey mudstones (samples TH1 and TH2).

The Chechiş Formation. Mudstones dominate the Chechiş Formation, although decimetric intercalations of ortoand paraconglomerates were observed (Fig. 3). The base of the coarse grained deposits is weakly erosional while the top becomes gradational. The extraformational pebbles are rounded to sub-rounded, suggesting feeding of the fan deltas by fluvial systems.

A glauconite rich interval is very characteristic for the lower part of the formation. Glauconite is well-known to be associated with periods of transgression and low deposition or even erosion of sediment (e.g., Rech-Frollo, 1963; McRae, 1972; Van Houten and Puruker, 1984; Harris and Whiting, 2000; Gonzalez et al., 2004). Cattaneo and Steel (2003) associated the maximum flooding surface (MFS) with condensed sections showing reduced oxygen values, high organic matter content, authigenic material (e.g., glauconite), abundant and diverse plankton, and low amounts of benthic foraminifera. Leckie and Olson (2003) associated the glauconite rich fine-grained deposits with the MFS, while Miller et al. (1997) associated the shelly sands with glauconite with transgressive systems tracts (TST) deposited in inner-middle neritic (0 to $100 \mathrm{~m}$ ) environments. Other authors related the MFS with: grey-brown clays with glauconite
(Danielsen et al., 1997), glauconite bearing deposits (Christensen et al., 1995), glauconite with peak abundances of Uvigerina (Browning et al., 1997), peaks in total organic carbon (Miller and Lohmann, 1982) during times of maximum flooding (Loutit et al., 1988), or condensed sections containing glauconite and/or siderite (Posamentier and Allen, 1999; Cătuneanu, 2006). Concentration of glauconite and increasing numbers of planktonic foraminifera were used to point to the MFS and the beginning of Highstand Systems Tracts in the Miocene of the Vienna Basin (Kováč et al., 2004).

The Coruş Formation was associated with the first Miocene marine transgression in the Transylvanian Basin (Popescu et al., 1995; Filipescu, 2011). The glauconite facies from the base of the Chechiş Formation was reported by Şuraru (1967) in the Coruş-Cristolţel area. For all reasons mentioned above, we assumed that the glauconitic level clearly identified at Tihău and in other occurrences of the Chechiş Formation corresponds to the maximum flooding surface of the first Early Miocene transgression.

The Hida Formation. Turbiditic sedimentation, specific for the Hida Formation, was observed in the middle and upper part of the studied section (Fig. 3). These sediments are characterized by intervals with sands/fine gravels or sandstones with carbonate cement alternating with marly-clays. Complete and incomplete Bouma sequences, erosional and deformational structures were recognized suggesting the deposition of the turbidites in mid-fan settings.

\section{FORAMINIFERAL ASSEMBLAGES}

Foraminiferal assemblages are abundant in the studied section and the preservation of the individuals varies from moderate to good. Among the identified foraminifera species, 35 are agglutinated benthic, 123 calcareous benthic, and 40 are planktonic (Appendix $1^{*}$ ).

Benthic foraminifera are well-represented along the section (Fig. 4), both in the Chechiş and Hida formations. The benthic assemblages are more diverse in the mudstones of the Chechiş Formation and less abundant and diverse in the fine turbidites of the Hida Formation (samples T13 to T17; Fig. 3).

Planktonic foraminifera are relatively well-represented in samples $\mathrm{T} 1$ to $\mathrm{T} 17$ (Fig. 3). The common species are: Globigerina angulisuturalis, G. anguliofficinalis, G. bollii, G. bulloides (Fig. 5D), G. ciperoensis, G. dubia, G. falconensis, G. gnaucki (Fig. 5C), G. lentiana (Fig. 5A), G. officinalis, G. ottnangiensis, G. praebulloides, G. tarchanensis, G. wagneri, Globoturborotalita woodi (Fig. 5E), Globigerinoides trilobus (Fig. 5F and G), Glob. quadrilobatus (Fig. 5I), Paragloborotalia continuosa, $P$. semivera, Tenuitellinata angustiumbilicata, $T$. pseudoedita, and T. juvenilis.

Planktonic foraminifera. The planktonic assemblages from Tihău are mostly dominated by species indicating cold-temperate water and high primary productivity (Globigerina group; Globoturborotalita woodi; Tenuitellinata, Tenuitella, and Catapsydrax species - Li et al., 1992; Spezzaferri, 1994, 1995; Spezzaferri and Ćorić, 2001; Spezzaferri et al., 2002; Rögl and Spezzaferri, 2003; Bicchi et al., 2003, 2006; Roetzel et al., 2006). Warm-temperate surface waters are suggested by the presence of Globigerinoides (e.g., Globigerinoides trilobus, G. primordius, G. quadrilobatus) and Paragloborotalia (e.g., Paragloborotalia continuosa, $P$. semivera) groups, and the species Globigerina ciperoensis (Spezzaferri, 1994; Rögl and Spezzaferri, 2003; Bicchi et al., 


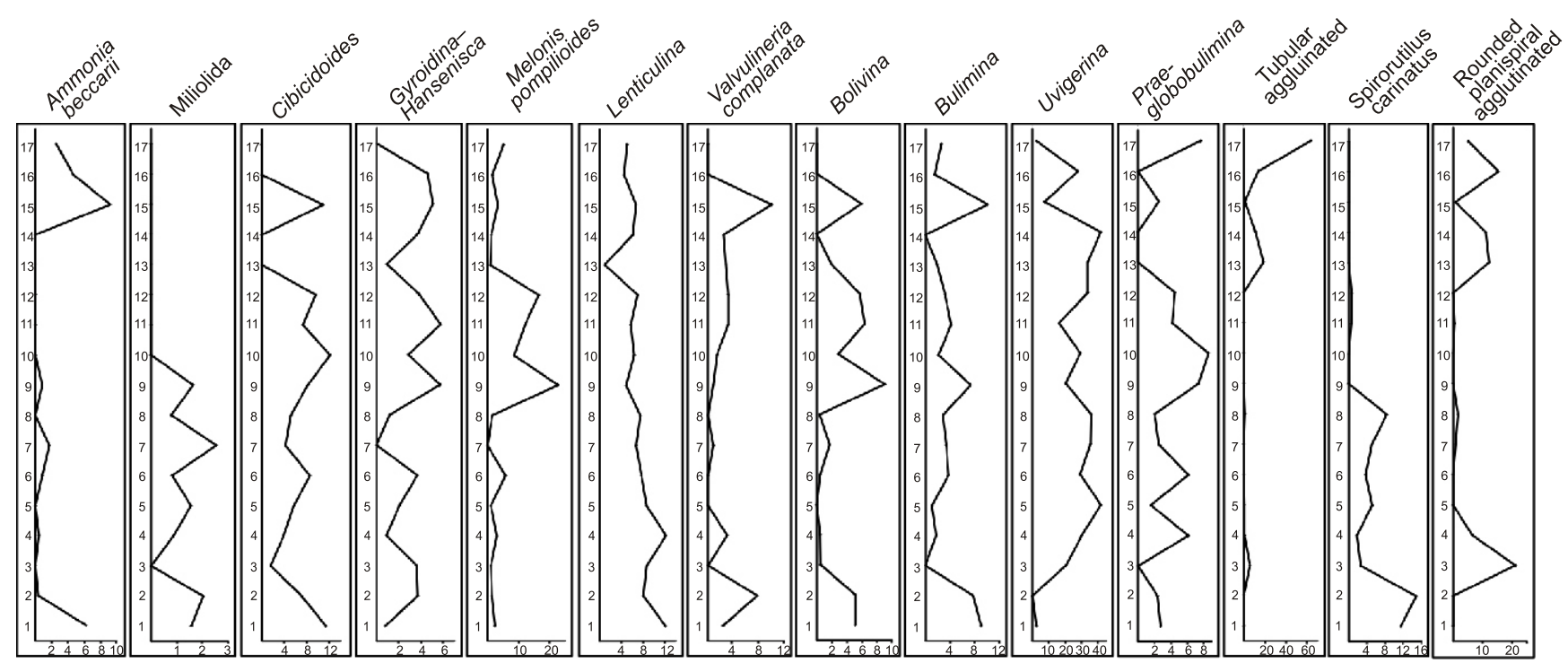

Fig. 4. The percent (relative to total benthic abundance) of most important benthic foraminifera species, genera and groups with similar palaeoecological affinities for samples T1-T17

2003; Amore et al., 2004). A surface water warming trend was identified in samples T2-T7 (Chechiş Formation), with gradually increasing amounts of Globigerinoides trilobus and a decrease in the abundance of Globigerina ottnangiensis. The abundance of Globigerinoides trilobus abruptly drops in the following samples. The development of planktonic assemblages was probably influenced by a change in either the productivity or temperature of surface waters.

The deposition of the Chechiş Formation was generally correlated with an Eggenburgian warming interval (characterized by the Parvamussium duodecimlamellatum-Pecten hornensis Biozone, NN2 - Discoaster druggi Biozone and also by the M1 and M2 plantkonic foraminifera zones - Nicorici et al., 1979; Moisescu and Popescu, 1980; Chira et al., 2000). Based on microflora assemblages, Petrescu et al. (2000) characterized this interval as developed in a warm, subtropical climate. Cooling episodes in the Transylvanian Basin were recorded only for the Ottnangian (Moisescu and Popescu, 1980; Chira et al., 2000). The warming trend identified at Tihău probably approximates the event documented by palynological data by Tabără and Chirilă (2012) for the middle part of the Eggenburgian.

The good representation of the cool-temperate surface water planktonic species at Tihău may be also related to other palaeoecological factors such as primary productivity. Nevertheless, the scarcity of Mediterranean elements and the lack of low latitude planktonic foraminifera in the Coruş and Chechiş formations mentioned by Popescu et al. (1995) suggest complex palaeogeographic settings due to the geotectonic evolution.

Planktonic foraminifera are generally absent or scarce across much of the inner and middle shelf and their abundance rapidly increases across the outer shelf and upper slope (e.g., Phleger, 1951; Grimsdale and van Morkhoven, 1955; Bandy, 1956; Gibson, 1989; Van der Zwaan et al., 1990; Leckie and Olson, 2003). The planktonic/benthic ratio could be influenced by various factors, such as variations in salinity, productivity, oxygenation and connection with the world oceans (e.g., Ulleberg, 1974; Naidu and Malmgren, 1995; Van Hinsbergen et al., 2005). Although, the planktonic/benthic ratio is not only related to water depth, we consider it as an indicator of changes in paleobathymetry. The planktonic/benthic ratio is poorly represented in the sediments (samples $\mathrm{TH}_{1}$ and $\mathrm{TH} 2$ ) above the glauconite rich deposits, while the remaining samples (T1-T12) belonging to the Chechiş Formation display frequent oscillations between 20 to $70 \%$. In the upper part of section (the Hida Formation, samples T13-T17) the P/B ratio (between 40-70\%) displays an increasing trend followed by a decrease (Fig. 3).

Biostratigraphic analysis revealed the presence of the planktonic species Globigerinoides trilobus (samples T1-T12 and T14, T15; Fig. 5F and G), which can be associated with the Globigerinoides trilobus Biozone (Aquitanian-Burdigalian) of Popescu (1975). Additionally, according to Cicha et al., (1998) the stratigraphic range of the species Globigerina ottnangiensis (samples TH2-T12 and T14-T17; Fig. 5B) and Globigerina dubia (samples TH2-T4, T7-T12 and T14-T16) in the Central Paratethys is Eggenburgian-Karpatian. Therefore, based on the identified planktonic foraminifera species, the studied interval can be assigned to the Burdigalian.

Benthic foraminifera. Iva (1971) described a foraminiferal assemblage from the type section of the Corus Formation, but foraminifera have not been described from this unit at Tihău.

Samples $\mathrm{TH} 1$ and $\mathrm{TH} 2$ were recovered from the base of Chechiş Formation (Fig. 3). The low diversity benthic assemblage from the lowermost sample (TH1; Fig. 3 ) is characterized by Reticulophragmium venezuelanum (Fig. 6I), Budashevaella multicamerata (Fig. 6G), Textularia spp., Neugeborina longiscata, Uvigerina spp., and very rare planktonic foraminifera. According to Murray (2006), the agglutinated genus Textularia is an epifaunal form that prefers hard substrates with a depth range up to $500 \mathrm{~m}$. Additionally, Kaminski et al. (2005) included Budashevaella multicamerata in the M2b morphogroup of shelf to deep-marine agglutinated foraminifera, while Nagy et al. (2000) reported the same species as dominant in outer neritic to upper bathyal settings. Reticulophragmium venezuelanum has been found in deep-water settings of Angola, Cameroon (Seiglie and Baker, 1982; Preece, 1999), Venezuela (Preece, 1999), and India (Govindan, 2004). The calcareous Uvigerina from the same sample appears rarely in settings shallower than $100 \mathrm{~m}$ and it is also found in low-oxygen environments (Spezzaferri et al., 2002; Rögl and Spezzaferri, 2003). Based on the depth range of the constituent species, the sediments corresponding to sample $\mathrm{TH} 1$ were probably deposited in a transitional environmental between the outer neritic and upper 


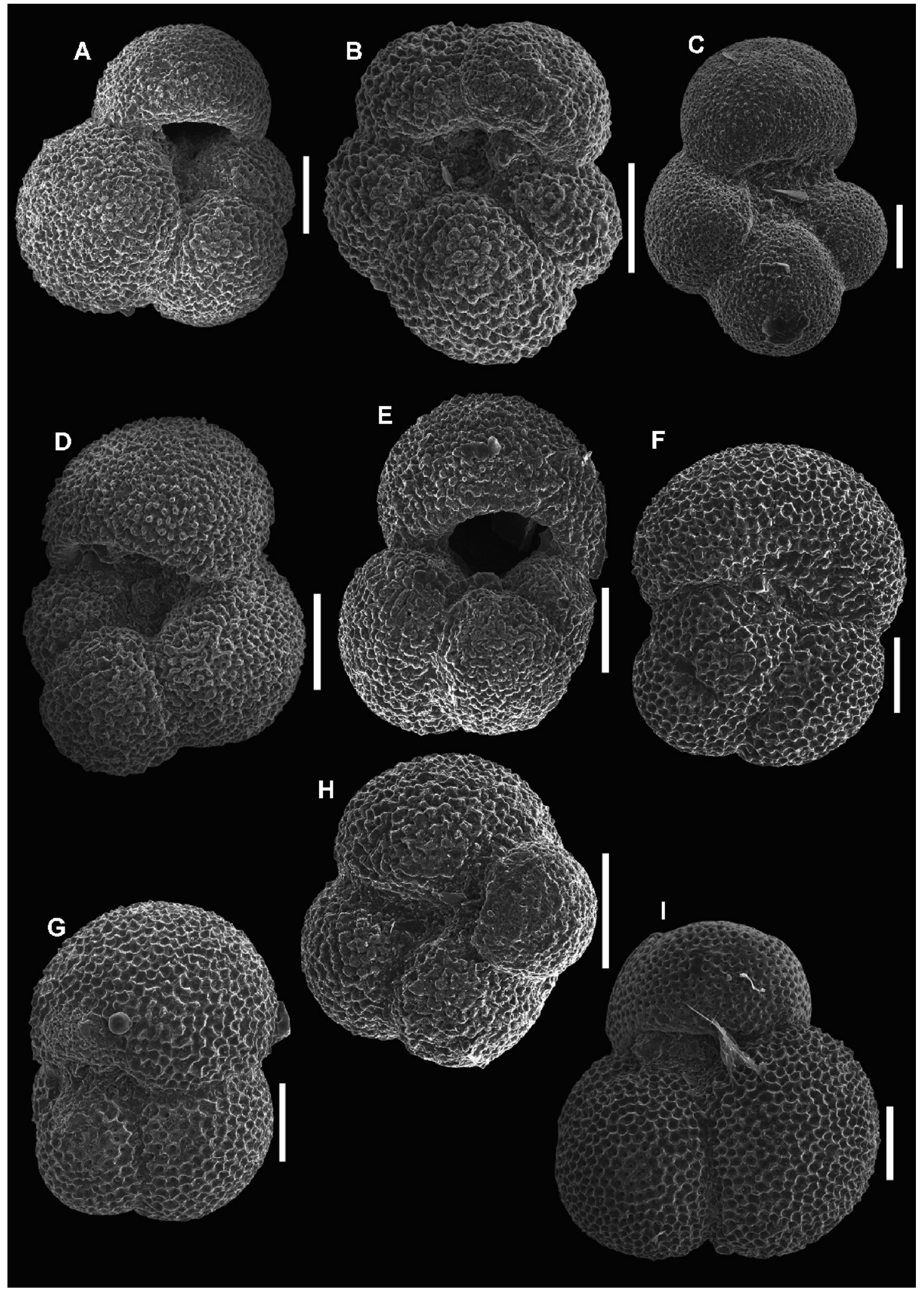

Fig. 5. Planktonic foraminifera from the Tihău section, Chechiş Formation

A - Globigerina lentiana Rögl, sample T4; B - Globigerina ottnangiensis Rögl, sample T5; C - Globigerina gnaucki Blow \& Banner, sample T10; D - Globigerina bulloides d'Orbigny, sample T10; E - Globoturborotalita woodi (Jenkins), sample T4; F - Globigerinoides trilobus (Reuss), sample T7; G - Globigerinoides trilobus (Reuss), sample T7; H - Catapsydrax unicavus (Bolli), sample T8; I - Globigerinoides quadrilobatus (d'Orbigny), sample T5; A-E, G-I - apertural view; F - spiral view; all scales represent $100 \mu \mathrm{m}$ 


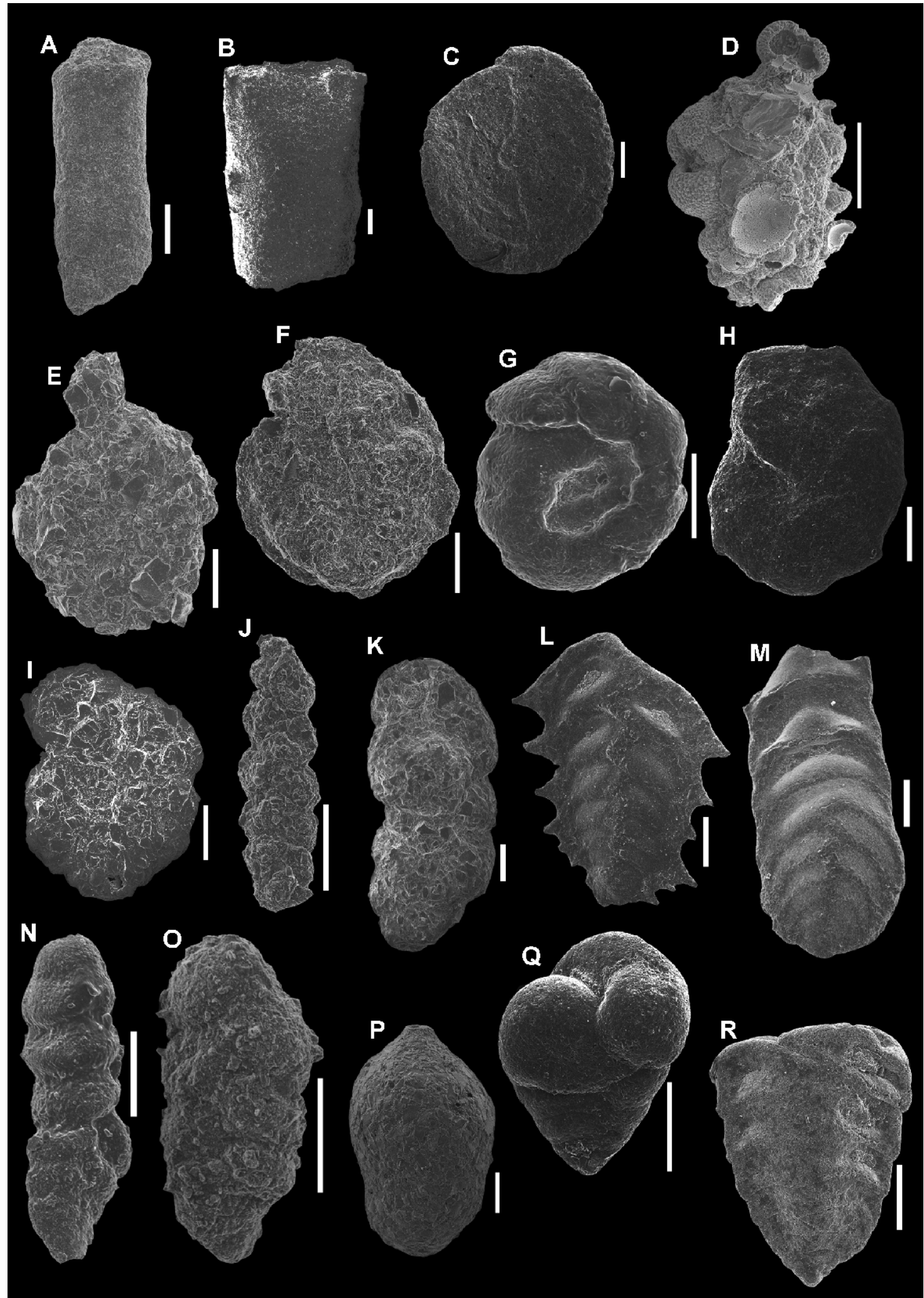

Fig. 6. Benthic foraminifera from the Tihău section

(Chechiş Formation - A, C, E-O, Q-R and Hida Formation - B, D, P)

A - Bathysiphon taurinensis Sacco, sample TH1; B - Nothia robusta (Grzybowski), sample T14; C - Ammodiscus miocenicus Karrer, sample T4; D - Psammosphaera fusca Schultze, sample T14; E - Saccammina grzybowskii (Schubert), sample TH1; F - Haplophragmoides carinatus Cushman \& Renz, sample TH1; G - Budashevaella multicamerata (Voloshinova), sample TH2; H - Reticulophragmium acutidorsatum (Hantken), sample T3; I - Reticulophragmium venezuelanum (Maync), sample T4; J - Karrerulina apicularis (Cushman), sample TH1; K - Gaudryinopsis beregoviensis (Venglinskyi), sample T3; L - Spirorutilus carinatus (d'Orbigny), sample T4; M - Vulvulina haeringensis (Gümbel), sample T5; N - Bigenerina agglutinans Cushman \& Ellisor, sample TH2; O - Textularia laevigata d'Orbingy, sample T1; P - Cylindroclavulina rudis (Costa), sample T14, Hida Formation; Q - Karreriella chilostoma (Reuss), sample T5; $\mathbf{R}$ - Semivulvulina deperdita (d'Orbigny), sample T5; A-R - side views; all scales represent $200 \mu \mathrm{m}$ 
bathyal. The very low species diversity of the benthic assemblage and dominance of these agglutinated foraminifera suggest a stressed palaeoenvironment, possibly characterized by intervals of high primary productivity and low-oxygen conditions at the bottom waters.

Sample TH2 (Fig. 3) exhibits a higher diversity of the benthic assemblage, with agglutinated and calcareous forms, suggesting more stable conditions on the substrate. Calcareous benthic forms are represented by the highly dominating Uvigerina popescui (indicator of high primary productivity Fig. 7C), Amphicoryna (A. armata suggesting suboxic bottom water), Lenticulina (L. calcar, L. inornata), Marginulina (inner to outer neritic M. hirsuta - Culver, 1988; Fig. 8R), and Sphaeroidina (S. bulloides) species, and the less epifaunal oxic forms such as Cibicidoides pseudoungerianus. Spirorutilus carinatus (Fig. $6 \mathrm{~L}$ ) belongs to the M2c morphogroup of agglutinated foraminifera (Kaminski et al., 2005) and is typical for the shelf environment. The agglutinated forms (Budashevaella multicamerata, Haplophragmoides spp., Spirorutilus carinatus) together with calcareous benthic foraminifera suggest a possible shallowing of the depositional environment to an outer neritic setting characterized by high primary productivity and episodic oxygen depletion in bottom waters.

Marine assemblages observed at the base of the second outcrop (T1, T2; Figs. 3 and 4) indicate shallow-marine environments, with the highest species diversity indices for the Tihău section. Spirorutilus carinatus, Semivulvulina pectinata, and Vulvulina haeringensis (Fig. 6M) can be mentioned among the most abundant agglutinated forms. Calcareous benthic forms are represented by oxic species (e.g., Cibicidoides pachyderma - Fig. 7O; C. ungerianus, Lobatula lobatula, Heterolepa dutemplei - Fig. 7R), low-oxygen indicators as Bulimina and Bolivina (Figs. 7A and 8S), and shallow-water taxa such as Ammonia beccarii (Fig. 7U), Asterigerinata planorbis, species of Elphidium (Fig. 7S) and miliolids (Parker, 1948; Bradshaw, 1957, 1961; Bandy and Arnal, 1960; Haake, 1977; Scott et al., 1980; Poag, 1981; Albani and Serandrei Barbero, 1982; Jorissen, 1987; Walton and Sloan, 1990; Murray, 1991; Almogi-Labin et al., 1992, 1995; Pawlowski et al., 1995; Debenay et al., 1998; Alve and Murray, 1999; Buck et al., 1999; Debenay and Guillou, 2002; Hayward et al., 2004; Mendes et al., 2004; Spezzaferri et al., 2004; Pippèr and Reichenbacher, 2010). The increase in shallow-water taxa and abrupt decrease in Uvigerina species (which is rarely $<100 \mathrm{~m}-$ Rögl and Spezzaferri, 2003) compared to the samples below suggest a shift to oxygenated, low primary productivity middle-neritic (50-100 m) environments. The stable, well-oxygenated environment probably enabled the diversification of the assemblages. Furthermore, the $\mathrm{P} / \mathrm{B}$ ratio of this interval (between 20-35\%) supports the middle neritic depositional setting.

The following samples (T3, T4; Figs. 3 and 4) contain a high proportion of deep-water (bathyal to abyssal) agglutinated foraminifera (Govindan, 2004; Kaminski et al., 2005) such as Reticulophragmium venezuelanum, R. acutidorsatum (Fig. 6H), $R$. rotundidorsatum, Karrerulina conversa and fewer shelf-type taxa. Calcareous benthics are represented by species of Uvigerina (Fig. 7), Cibicidoides, Lenticulina (Fig. 8) and specimens of Hansenisca soldanii. The $\mathrm{P} / \mathrm{B}$ ratio is higher compared to the older samples (45-55\%). These assemblages probably originated in an outer neritic to upper bathyal environment.

The P/B ratio peaks in sample T7 (Fig. 3), probably by reaching the deepest environments on the shelf. The presence of miliolids and Ammonia beccarii (Figs. 3 and 4) is probably related to transportation of benthic foraminifera from shallower depths.
The uppermost samples collected from the Chechiş Formation (T9-T12; Figs. 3 and 4) suggest a trend of oxygen depletion (Bulimina and Bolivina species) and high primary productivity (Melonis pompilioides, Valvulineria complanata, Uvigerina popescui, Praeglobobulimina ovata - Fig. 7B), even if episodes of well-oxygenated substrates were present.

The onset of turbiditic sedimentation of the Hida Formation (T13-T17) changed the composition of the foraminifera assemblages, which became less abundant and diverse, mostly dominated by agglutinated benthic foraminifera (Fig. 3). These are represented by tubular (M1 morphogroup - e.g., Bathysiphon taurinensis Fig. 6A, Hyperammina spp., and Rhizammina spp.), rounded planispiral (M4a morphogroup - e.g., Cyclammina cancellata, Haplophragmoides spp., Reticulophragmium acutidorsatum, $R$. rotundidorsatum), rounded trochospiral (M2b morphogroup - e.g., Budashevaella multicamerata, Cribrostomoides spp.), flattened planispiral (M3a morphogroup - e.g. Ammodiscus miocenicus - Fig. 6C; Popovia spp.), and elongate subcylindrical (M4b morphogroup - e.g., Cylindroclavulina rudis Fig. 6P) forms. Shallow-water taxa are rare (e.g., Vulvulina haeringensis). These forms are characteristic for an upper bathyal depositional setting.

Calcareous benthic forms are represented by species of Cibicidoides, Lenticulina, specimens of Hansenisca soldanii, Melonis pompilioides, Praeglobobulimina ovata, Uvigerina popescui, U. graciliformis, Valvulineria complanata, and rare Bulimina, Bolivina, and Stilostomella (Fig. $7 \mathrm{~L}$ and M) species (Fig. 4). The presence of Ammonia beccarii and other calcareous benthic species in samples T15-T17 may be an evidence for advancing shallower environments due to an increased progradation. The initial deepening trend followed by shallowing is confirmed by the P/B ratio (Fig. 3), with higher values in the lower Hida Formation (samples T13 and T14) and a subsequent gradual drop (samples T14-T17).

\section{SUCCESSION OF PALAEOENVIRONMENTS}

The interpretation of sedimentological trend and succession of foraminifera assemblages allowed the reconstruction of palaeoenvironments succession in the Chechiş and Hida Formations. The lowermost benthic foraminifera assemblage from the Chechiş Formation (sample TH1; Fig. 3) indicates an outer-neritic to upper bathyal palaeoenvironment (characterized by high primary productivity) for the sedimentary succession above the interval with glauconite representing the maximum flooding surface. The sediments above the glauconite can be associated to the Highstand Systems Tract deposited during the late stage of the relative sea level rise. A shallowing of the depositional setting (outer neritic) was observed in sample TH2. This trend was also observed in sample T2, where the palaeoenvironment was probably characterized by a $50-100 \mathrm{~m}$ palaeodepth. Shallow environments were characterized by a good oxygenation of the bottom waters and a low primary productivity. The upper part of the Chechiş Formation (samples T3-T12) is characterized by minor palaeodepth oscillations occurring in an outer neritic environment (an aggradational stacking pattern of the parasequences), and episodes of high primary productivity. Bottom waters were relatively well oxygenated and probably alternated with episodes of oxygen depletion. In the uppermost part of the Chechiş Formation, benthic foraminifera assemblages suggest intense high primary productivity and enhanced oxygen depletion in the bottom waters. The frequent environmental shifts in the Chechiş Formation 


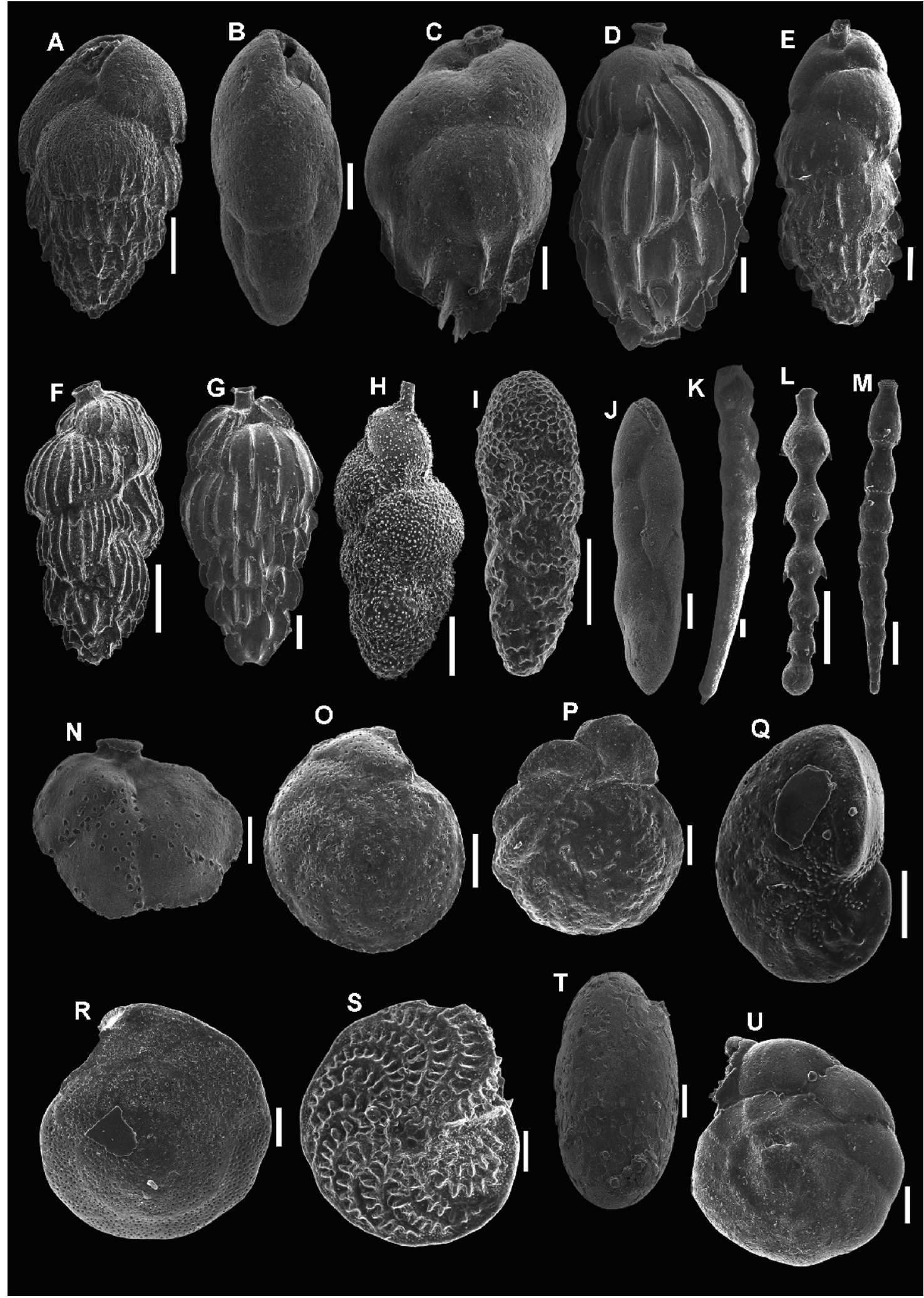

Fig. 7. Benthic foraminifera from the Tihău section (Chechiş Formation)

A - Bulimina striata striata d'Orbigny, sample T2; B - Praeglobobulimina ovata (d'Orbigny), sample T4; C - Uvigerina popescui Rögl, sample T4; D - Uvigerina posthantkeni Papp, sample TH2; E - Uvigerina continuosa Lamb, sample TH1; F - Uvigerina graciliformis Papp \& Turnovsky, sample TH1; G - Uvigerina acuminata Hosius, sample T8; H - Uvigerina farinosa (Hantken), sample T5; I - Lapugyina schmidi Popescu, sample T2; J - Fursenkoina acuta (d'Orbigny), sample T2; K - Siphonodosaria consobrina (d'Orbigny), sample T1; L - Stilostomella adolphina (d'Orbigny), sample T2; M Stilostomella bradyi (Cushman), sample T2; $\mathbf{N}$ - Siphonina reticulata (Czjzek), sample T5; O - Cibicidoides pachyderma (Rzehak), sample T8; P - Cibicidoides pseudoungerianus (Cushman), sample T8; Q - Nonion commune (d'Orbigny), sample T7; R - Heterolepa dutemplei (d'Orbigny), sample T8; S - Elphidium ortenburgense (Egger), sample T7; T Chilostomella oolina Schwager, sample T4; U - Ammonia beccarii (Linné), sample T7; Q, S, T - side views; O, P, R, U spiral views; all scales represent $100 \mu \mathrm{m}$ 


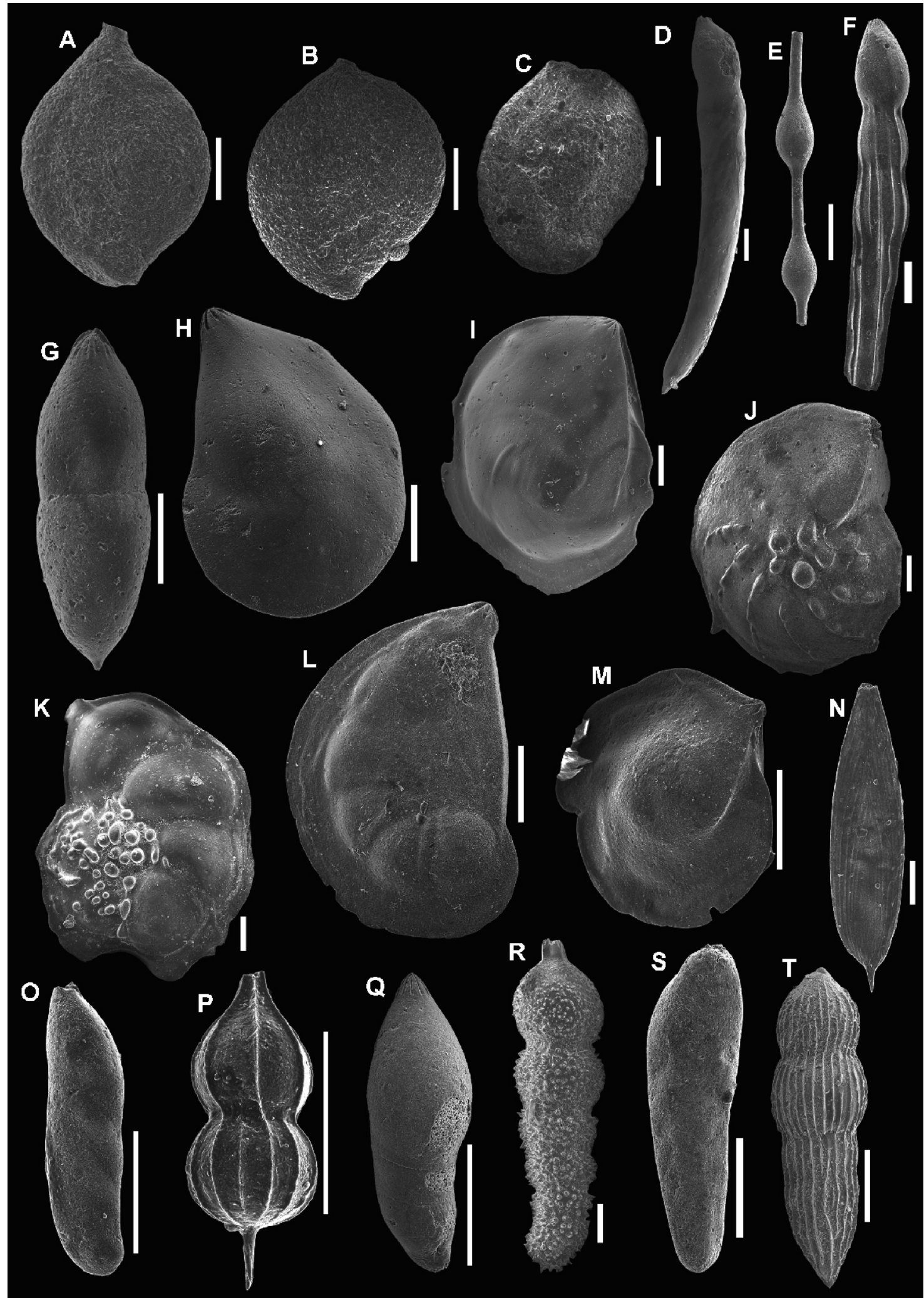

Fig. 8. Benthic foraminifera from the Tihău section (Chechiş Formation)

A - Sigmoilopsis colomi (Glaçon \& Magné), sample T2; B - Sigmoilopsis ottnangensis (Cicha, Ctyroka \& Zapletalova), sample T5; C - Sigmoilopsis schlumbergeri (Silvestri), sample T3; D - Laevidentalina elegans (d'Orbigny), sample TH2; E - Grigelis pyrula (d'Orbigny), sample T4; F - Dentalina acuta d'Orbigny, sample T5; G - Pseudonodosaria discreta (Reuss), sample T8; H - Lenticulina gibba (d'Orbigny), sample TH2; I - Lenticulina cultrata (Montfort), sample TH2; J Lenticulina subpapillosa (Nuttall), sample T2; K - Lenticulina budensis (Hantken), sample TH2; L - Lenticulina reniformis (d'Orbigny), sample T3; $\mathbf{M}$ - Lenticulina sp., sample T8; $\mathbf{N}$ - Frondovaginulina tenuissima (Hantken), sample T7; $\mathbf{O}$ - Marginulinopsis tenuis (Bornemann), sample T2; P - Pyramidulina catesbyi (d'Orbigny), sample T2; Q Marginulina similis d'Orbigny, sample T8; $\mathbf{R}$ - Marginulina hirsuta d'Orbigny, sample TH2; $\mathbf{S}$ - Bolivina antiqua d'Orbigny, sample T5; T - Siphogenerinoides vasarhelyi (Hantken), sample T8; A-T - side views; all scales represent $200 \mu \mathrm{m}$ 
were probably the result of changing rates between relative sea level and sedimentary input from the land (sedimentation associated with fan deltas on a narrow shelf). The sedimentary log and succession of assemblages confirms the transition to the progradational stacking pattern during the late highstand.

The regional tectonics influenced the sedimentation trend starting with the deposition of Hida Formation. The tectonic thrust of the Pienides (Krézsek and Bally, 2006) produced a deepening (upper bathyal) of the environments from the lower Hida Formation, as suggested by deep-water agglutinated foraminifera assemblages (similar to those described by Filipescu and Beldean, 2008; Beldean and Filipescu, 2011; Beldean et al., 2011) and by the onset of the turbiditic sedimentation. The shift to a clear progradational stacking pattern is demonstrated by the shallowing interval from the middle part of the formation, where calcareous benthic forms become significant. The transport from shallower environments and progradational trend become stronger in the upper part of the formation.

\section{CONCLUSIONS}

The Early Miocene succession of palaeonvironments observed in the Tihău section is related to the particular evolution of the Transylvanian Basin under global and regional control.

The biostratigraphic study enables the correlation of the sediments with the Globigerinoides trilobus Biozone of Popescu (1975) indicating a Burdigalian age for the deposits.

A potential warming event during the second part of the Eggenburgian (Chechiş Formation) has been observed based on the temperature preferences of planktonic foraminifera assemblages. This event shows correlation potential to global events, although a calibration is almost impossible by planktonic foraminifera only. Additionally, the presence of small sized planktonic foraminifera suggests episodic high primary productivity.

Frequent shifts between middle neritic to upper bathyal palaeoenviromnents were observed in the Chechiş Formation, while an upper bathyal depositional setting was restored for the Hida Formation. The distribution of the calcareous benthic foraminiferal assemblages throughout the section indicate fluctuations in primary productivity and bottom water oxygenation.

The sedimentology of the studied section together with foraminiferal assemblages allowed the delineation of the evolution of the sedimentary basin:

- the coarse grained littoral deposits of the Coruş Formation represent the first term of Early Miocene marine transgression in the Transylvanian Basin;

- the glauconite facies from the base of the Chechiş Formation can be associated with the maximum flooding surface:

- the deposition of the sediments belonging to the middle and upper part of the Chechiş Formation produced on a narrow shelf, probably under the influence of prograding deltas during the subsequent highstand;

- the turbiditic sedimentation specific for the Hida Formation probably was also associated to the highstand systems tract, but influenced by regional tectonic control (uplifting of the Pienides to the north).

The studied section provides an overview on the distribution in time and space of the foraminiferal assemblages and sedimentary environments from the northwestern Transylvanian Basin; it provides criteria for facies correlation and allows the reconstruction of a part of the regional evolution under tectonic control.

Acknowledgements. We are grateful to the reviewers M. Kaminski and A. Waśkowska, and the GQ editor T.M. Peryt for their suggestions, comments and corrections which helped improving the paper. The research of S-.F. Székely and R. Bindiu was made possible by the financial support of the Sectoral Operational Programme for Human Resources Development 2007-2013, co-financed by the European Social Fund, under the project POSDRU/159/1.5/S/133391 - "Doctoral and postdoctoral excellence programs for training highly qualified human resources for research in the fields of Life Sciences, Environment and Earth". The Grzybowski Foundation's "Brian J. O'Neill Memorial Grant in-Aid" and the S.N.G.N. Romgaz (Contract 18/2011) are also warmly thanked for financial support.

\section{REFERENCES}

Albani, A.D., Serandrei Barbero, R., 1982. A foraminiferal fauna from the Lagoon of Venice, Italy. Journal of Foraminiferal Research, 12: 234-241.

Alegret, L., Cruz, L.E., Fenero, R., Molina, E., Ortiz, S., Thomas, E., 2008. Effects of the Oligocene climatic events on the foraminiferal record from Fuente Caldera section (Spain, western Tethys). Palaeogeography, Palaeoclimatology, Palaeoecology, 269: 94-102.

Almogi-Labin, A., Perelis-Grossovicz, L., Raab, M., 1992. Living Ammonia from a hypersaline inland pool, Dead Sea area, Israel. Journal of Foraminiferal Research, 22: 257-266.

Almogi-Labin, A., Siman-Tov, R., Rosenfeld, A., Debard, E., 1995. Occurrence and distribution of the foraminifer Ammonia beccarii tepida (Cushman) in water bodies, Recent and Quaternary, of the Dead Sea Rift, Israel. Marine Micropaleontology, 26: 153-159.

Alve, E., Murray, J.W., 1999. Marginal marine environments of the Skagerrak and Kattegat: a baseline study of living (stained) benthic foraminiferal ecology. Palaeogeography, Palaeoclimatology, Palaeoecology, 146: 171-193.
Amore, F.O., Caffaub, M., Massaa, B., Morabito, S., 2004. Late Pleistocene-Holocene paleoclimate and related paleoenvironmental changes as recorded by calcareous nannofossils and planktonic foraminifera assemblages in the southern Tyrrhenian Sea (Cape Palinuro, Italy). Marine Micropaleontology, 52: 255-276.

Bandy, O.L., 1956. Ecology of foraminifera in the northeastern Gulf of Mexico. U.S. Geological Survey, Professional Paper, 274-G: 179-204.

Bandy, O.L., Arnal, R.E., 1960. Concepts in foraminiferal paleoecology. AAPG Bulletin, 44: 1921-1932.

Beldean, C., Filipescu, S., 2011. "Flysch-type" agglutinated foraminifera from the Lower Miocene of the Transylvanian Basin (Romania). Grzybowski Foundation Special Publication, 16: 1-18.

Beldean, C., Filipescu, S., Bălc, R., 2010. An Early Miocene biserial foraminiferal event in the Transylvanian Basin (Romania). Geologica Carpathica, 61: 227-234.

Beldean, C., Filipescu, S., Aroldi, C., Iordache, Gh., Bindiu, R., 2011. Foraminiferal assemblages and Early Miocene 
paleoenvironments in the NW Transylvanian Basin. Acta Palaeontologica Romaniae, 7: 9-16.

Beldean, C., Filipescu, S., Bălc, R., 2012. Paleoenvironmental and biostratigraphic data for the Early Miocene of the north-western Transylvanian Basin based on planktonic foraminifera. Carpathian Journal of Earth and Environmental Sciences, 7: 171-184.

Berggren, W.A., Kent, D.V., Swisher III, C.C., Aubry, M.P.A., 1995. Revised Cenozoic geochronology and chronostratigraphy. SEPM Special Publication, 54: 129-212.

Bicchi, E., Ferrero, E., Gonera, M., 2003. Palaeoclimatic interpretation based on Middle Miocene planktonic Foraminifera: the Silesia Basin (Paratethys) and Monferrato (Tethys) records. Palaeogeography, Palaeoclimatology, Palaeoecology, 196: 265-303.

Bicchi, E., Dela Pierre, F., Ferrero, E., Maia, F., Negri, A., Pirini Radrizzani, C., Radrizzani, S., Valleri, G., 2006. Evolution of the Miocene carbonate shelf of Monferrato (North-western Italy). Bollettino della Societa Paleontologica Italiana, 45: 171-194.

Bombiţă, G., 1966. Contribuţii la studiul geologic al regiunii Băiuţ-Poiana Botizii. Dări de Seamă Ale Şedinţelor, 52: 203-223.

Bradshaw, J.S., 1957. Laboratory studies on the rate of growth of the foraminifer "Streblus beccarii (Linné) var. tepida (Cushman)". Journal of Paleontology, 31: 1138-1147.

Bradshaw, J.S., 1961. Laboratory experiments on the ecology of foraminifera. Contributions from the Cushman Foundation for Foraminiferal Research, 12: 87-106.

Browning, J.V., Miller, K.G., Bybell, M.L., 1997. Upper Eocene sequence stratigraphy and the Absecon Inlet Formation, New Jersey Coastal Plain. Proceedings of the Ocean Drilling Program, Scientific Results, 150X: 243-266.

Buck, K., Olson, H.C., Austin, J.A., 1999. Paleoenvironmental evidence for latest Pleistocene sea-level fluctuations on the New Jersey outer continental shelf: Combining high-resolution sequence stratigraphy and foraminiferal analysis. Marine Geology, 154: 287-304.

Cattaneo, A., Steel, R.J., 2003. Transgressive deposits: a review of their variability. Earth-Science Reviews, 62: 187-228.

Cătuneanu, O., 2006. Principles of Sequence Stratigraphy. Elsevier, Amsterdam

Chira, C., Filipescu, S., Codrea, V., 2000. Palaeoclimatic evolution in the Miocene from the Transylvanian Depression reflected in the fossil record. Geological Society Special Publications, 181: $55-64$

Christensen, B.A., Miller, K.G., Olsson, R.K., 1995. Eocene-Oligocene benthic foraminiferal biofacies and depositional sequences at the ACGS \#4 Borehole, New Jersey Coastal Plain. Palaios, 10: 103-132.

Cicha, I., Rögl, F., Rupp, Ch., Ctyroka, J., 1998. Oligocene-Miocene Foraminifera of the Central Paratethys. Abhandlungen der Senckenbergischen Naturforschenden Gesellschaft, 549.

Corliss, B.H., Chen, C., 1988. Morphotype patterns of Norwegian Sea deep-sea benthic foraminifera and ecological implications. Geology, 16: 716-719.

Corliss, B.H., Fois, E., 1990. Morphotype analysis of deep-sea benthic foraminifera from the Northwest Gulf of Mexico. Palaios, 5-6: 589-605.

Culver, S.J., 1988. New foraminiferal depth zonation of the northwestern Gulf of Mexico. Palaios, 3: 69-85.

Danielsen, M., Michelsen, O., Clausen, O.R., 1997. Oligocene sequence stratigraphy and basin development in the Danish North Sea sector based on log interpretations. Marine and Petroleum Geology, 14: 931-950.

De Leeuw, A., Filipescu, S., Maţenco, L., Krijgsman, W., Kuiper, K., Stoica, M., 2013. Paleomagnetic and chronostratigraphic constraints on the evolution of the middle Miocene Transylvanian Basin (Romania) and their implications for Central Paratethys stratigraphy and the emplacement of the Tisza-Dacia plate. Global and Planetary Change, 103: 82-98.
Debenay, J.P., Guillou, J.J., 2002. Ecological transitions indicated by foraminiferal assemblages in paralic environments. Estuaries, 25: 1107-1120.

Debenay, J.P., Bénéteau, E., Zhang, J., Stouff, V., Geslin, E., Redois, F., Fernandez-Gonzalez, M., 1998. Ammonia beccarii and Ammonia tepida (Foraminifera): morphofunctional arguments for their distinction. Marine Micropaleontology, 34: 235-244.

Dicea, O., Duţescu, P., Antonescu, F., Mitrea, G., Botez, R., Donos, I., Lungu, V., Moro?anu, I., 1980. Contribution to the knowledge of Maramures's Transcarpathian Zone stratigraphy (in Romanian). Dări de Seamă ale Institutului de Geologie şi Geofizică, 65: 21-85.

Filipescu, S., 2011. Cenozoic lithostratigraphic units in Transylvania. In: Calcareous algae from Romanian Carpathians. Field Trip Guide Book, Tenth International Symposium on Fossil Algae, Cluj-Napoca, Romania, 12-18 September (eds. I.I. Bucur and E. Săsăran): 37-48. Cluj University Press.

Filipescu, S., Beldean, C., 2008. Foraminifera in the deep-sea environments of the Hida Formation (Transylvanian Basin, Romania). Acta Palaeontologica Romaniae, 6: 105-114.

Filipescu, S., Silye, L., 2008. New Paratethyan biozones of planktonic foraminifera described from the Middle Miocene of the Transylvanian Basin. Geologica Carpathica, 59: 537-544.

Filipescu, S., Wanek, F., Miclea, A., De Leeuw, A., Vasiliev, I., 2011. Micropaleontological response to the changing paleoenvironment across the Sarmatian-Pannonian boundary in the Transylvanian Basin (Miocene, Oarba de Mureş section, Romania). Geologica Carpathica, 62: 91-102.

Gibson, T.G., 1989. Planktonic:benthonic foraminiferal ratios: modern patterns and Tertiary applicability. Marine Micropaleontology, 15: 29-52.

Gonzalez, R., Dias, J.M.A., Lobo, F., Mendes, I., 2004 Sedimentological and paleoenvironmental characterization of transgressive sediments on the Guadiana Shelf (Northern Gulf of Cadiz, SW Iberia). Quaternary International, 120: 133-144.

Govindan, A., 2004. Miocene deep water agglutinated foraminifera from offshore Krishna-Godavari Basin, India. Micropaleontology, 50: 213-252.

Gradstein, F.M., Ogg, J.G., eds., 2004. A Geologic Time Scale 2004. Cambridge University Press, Cambridge.

Grimsdale, T.F., van Morkhoven, F.P.C.M., 1955. The ratio between pelagic and benthonic foraminifera as a means of estimating depth of deposition of sedimentary rocks. Proceedings of the Fourth World Petroleum Congress Section I/D: 474-491.

Haake, F.W., 1977. Living benthic foraminifera in the Adriatic Sea: influence of water depth and sediment. Journal of Foraminiferal Research, 7: 62-75.

Hammer, Ø., Harper, D.A.T., Ryan, P.D., 2001. PAST: paleontological statistics software package for education and data analysis. Palaeontologia Electronica, 4: 1-9.

Harris, L.C., Whiting, B.M., 2000. Sequence-stratigraphic significance of Miocene to Pliocene glauconite-rich layers, on- and offshore of the US Mid-Atlantic margin. Sedimentary Geology, 134: 129-147.

Hayward, B.W., Holzmann, M., Grenfell, H.R., Pawlowski, J., Triggs, C.M., 2004. Morphological distinction of molecular types in Ammonia - towards a taxonomic revision of the world's most commonly misidentified foraminifera. Marine Micropaleontology, 50: 237-271.

Iva, M., 1971. Microfaune de la coupe type des Couches de Coruş. Mémoires, Institut de Géologie et de Géophysique, 14: 53-69.

Jorissen, F.J., 1987. The distribution of benthic foraminifera in the Adriatic Sea. Marine Micropaleontology, 12: 21-48.

Jorissen, F.J., 1999. Benthic foraminiferal microhabitats below the sediment-water interface. In: Modern Foraminifera (ed. B.K. Sen Gupta): 161-179. Kluwer Academic Publishers.

Jorissen, F.J., Fontanier, C., Thomas, E., 2007. Paleoceanographical proxies based on deep-sea benthic foraminiferal assemblage characteristics. In: Developments in Marine Geology, 1. Proxies in Late Cenozoic Paleoceano- 
graphy, Part 2 - Biological tracers and biomarkers (eds. C. Hillaire-Marcel and A. de Vernal): 263-325. Elsevier.

Kaiho, K., 1994. Benthic foraminiferal dissolved-oxygen index and dissolved-oxygen levels in the modern ocean. Geology, 22: 719-722.

Kaiho, K., 1999. Effect of organic carbon flux and dissolved oxygen on the benthic foraminiferal oxygen index (BFOI). Marine Micropaleontology, 37: 67-76.

Kaminski, M.A., 2012. Calibration of the Benthic Foraminifera Oxygen Index in the Marmara Sea. Geological Quarterly, 56 (4) 757-764.

Kaminski, M.A., Gradstein, F.M., collaborators, 2005. Atlas of Paleogene Cosmopolitan Deep-water Agglutinated Foraminifera. Grzybowski Foundation Special Publication, 10.

Kouwenhoven, T.J., Van der Zwaan, G.J., 2006. A reconstruction of late Miocene Mediterranean circulation patterns using benthic foraminifera. Palaeogeography, Palaeoclimatology, Palaeoecology, 238: 373-385.

Kováč, M., Baráth, I., Harzhauser, M., Hlavatý, I., Hudáčková, N., 2004. Miocene depositional systems and sequence stratigraphy of the Vienna Basin. Courier Forschungsinstitut Senckenberg, 246: 187-212.

Krézsek, C., Bally, A.W., 2006. The Transylvanian Basin (Romania) and its relation to the Carpathian fold and thrust belt: Insights in gravitational salt tectonics. Marine and Petroleum Geology, 23 : 405-442.

Krézsek, C., Filipescu, S., 2005. Middle to late Miocene sequence stratigraphy of the Transylvanian Basin (Romania). Tectonophysics, 410: 437-463.

Krézsek., C., Filipescu, S., Silye, L., Maţenco, L., Doust, H., 2010. Miocene facies associations and sedimentary evolution of the Southern Transylvanian Basin (Romania): implications for hydrocarbon exploration. Marine and Petroleum Geology, 27 191-214.

Laskarev, V.N., 1924. Sur les equivalents du Sarmatien supérieur en Serbie. In: Receuil de traveaux offert à M. Jovan Cvijic par ses amis et collaborateurs (ed. P. Vujević): 73-85. Drzhavna Shtamparija.

Leckie, R.M., Olson, H.C., 2003. Foraminifera as proxies for sea-level change on siliciclastic margins. SEPM Special Publication, 75: 5-19.

Li, Q., Radford, S.S., Banner, F.T., 1992. Distribution of microperforate tenuitellid planktonic foraminifers in Holes 747A and 749B, Kerguelen Plateau. In: Proceedings of the Ocean Drilling Program, Scientific Results, 120: 569-594.

Loutit, T.S., Hardenbol, J., Vail, P.R., Baum, G.R., 1988. Condensed section: The key to age determination and correlation of continental margin sequences, SEPM Special Publication, 42: 183-213.

Martini, E., 1971. Standard Tertiary and Quaternary calcareous nannoplankton zonations. In: Proceedings of the II Planktonic Conference, Rome, 1970 (ed. A. Farinacci): 739-785. Editura Tecnoscienza, 2 .

McRae, S.G., 1972. Glauconite. Earth-Science Reviews, 8: 397-440.

Mendes, I., Gonzalez, R., Dias, J.M.A., Lobo, F., Martins, V., 2004 Factors influencing recent benthic foraminifera distribution on the Guadiana shelf (Southwestern Iberia). Marine Micropaleontology, 51: 171-192.

Miller, K.G., Lohmann, P., 1982. Environmental distribution of Recent benthic foraminifera on the northeast United States continental slope. GSA Bulletin, 93: 200-206.

Miller, K.G., Rufolo, S., Sugarman, P.J., Pekar, S.F., Browning, J.V., Gwynn, D.W., 1997. Early to middle Miocene sequences, systems tracts, and benthic foraminiferal biofacies, New Jersey coastal plain. In: Proceedings of the Ocean Drilling Program, Scientific Results, 150X: 169-186.

Moisescu, V., Popescu, Gh., 1980. Chattian-Badenian biochronology in Romania by means of molluscs. Anuarul Institutului de Geologie şi Geofizică, 56: 205-224.
Murray, J.W., 1991. Ecology and Palaeoecology of Benthic Foraminifera. Essex, UK, Longman Scientific and Technical.

Murray, J.W., 2006. Ecology and Applications of Benthic Foraminifera. Cambridge University Press.

Nagy, J., Kaminski, M.A, Kuhnt, W., Bremer, M.A., 2000. Agglutinated Foraminifera from Neritic to Bathyal facies in the Paleogene of Spitsbergen and the Barents Sea. Grzybowski Foundation Special Publication, 7: 333-361.

Naidu, P.D., Malmgren, B.A., 1995. Do benthic foraminifer records represent a productivity index in oxygen minimum zone areas? An evaluation from the Oman margin, Arabian Sea. Marine Micropaleontology, 26: 49-55.

Nicorici, E., Petrescu, I., Mészáros, N., 1979. Contribuţii la cunoaşterea miocenului inferior şi mediu de la Coasta cea Mare (Cluj-Napoca). Studii şi cercetări de geologie, geofizică, geografie. Seria Geologie, 24: 103-137.

Parker, F.L., 1948. Foraminifera of the continental shelf from the Gulf of Maine to Maryland. Harvard College, Museum of Comparative Zoology, Bulletin, 100: 213-241.

Pawlowski, J., Bolivar, I., Farhni, J., Zaninetti, L., 1995. DNA analysis of "Ammonia beccarii" morphotypes: one or more species? Marine Micropaleontology, 26: 171-178.

Pearson, P.N., Olsson, R.K., Huber, B.T., Hemleben, C. Berggren, W.A., 2006. Atlas of Eocene Planktonic Foraminifera. Cushman Foundation for Foraminiferal Research, Special Publication, $\mathbf{4 1}$

Petrescu, I., Popa, M., Bican-Brişan, N., 2000. The presence of Lower Miocene (Eggenburgian) in Borehole 575 Cetea (East of Borod Basin, NW ${ }^{\text {rn }}$ Romania). Studia Universitatis Babeş-Bolyai, Geologia, 45: 63-78.

Phleger, F.B., 1951. Ecology of Foraminifera, Northwest Gulf of Mexico, Part I. Foraminifera Distribution. GSA Memoir, 46

Pippèr, M., Reichenbacher, B., 2010. Foraminifera from the borehole Altdorf (SE Germany): Proxies for Ottnangian (early Miocene) palaeoenvironments of the Central Paratethys. Paleogeography, Palaeoclimatology, Palaeoecology, 289: 62-80.

Poag, C.W., 1981. Ecologic Atlas of Benthic Foraminifera of the Gulf of Mexico: Woods Hole, Massachusetts, Marine Science International.

Popescu, Gh., 1975. Études des foraminiféres du Miocène inférieur et moyen du nordouest de la Transylvanie. Mémoires, Institut de Géologie et de Géophysique, 23.

Popescu, Gh., Mărunţeanu, M., Filipescu, S. 1995. Neogene from Transylvania Depression. X. Congress RCMNS, Bucureşti 1995, Guide to excursion A1. Romanian Journal of Stratigraphy, 76: 1-27.

Posamentier, H.W., Allen, G.P., 1999. Siliciclastic Sequence Stratigraphy - Concepts and Applications. SEPM Concepts in Sedimentology and Paleontology, 7.

Preece, R.C., 1999. The physiological response of equatorial Neogene bathyal benthic foraminifera to low oxygen conditions. Unpublished Ph.D. thesis, University College London.

Rech-Frollo, M.M., 1963. Les conditions de formation de la glauconite en relation avec le flysch. Comptes Rendues de la Academie de Sciences de Paris, 257: 3011-3013.

Roetzel, R., Ćorić, S., Galović, I., Rögl, F., 2006. Early Miocene (Ottnangian) coastal upwelling conditions along the southeastern scarp of the Bohemian Massif (Parisdorf, Lower Austria, Central Paratethys). Beiträge zur Paläontologie, 30: 387-413.

Rögl, F., 1998. Palaeogeographic considerations for Mediterranean and Paratethys seaways (Oligocene to Miocene). Annalen des Naturhistorischen Museums in Wien, 99A: 279-310.

Rögl, F., Spezzaferri, S., 2003. Foraminiferal paleoecology and biostratigraphy of the Muhlbach section (Gaindorf Formation, Lower Badenian), Lower Austria. Annalen des Naturhistorischen Museums in Wien, 104A: 23-75.

Scott, D.B., Schafer, C.T., Medioli, F.S., 1980. Eastern Canadian estuarine foraminifera: a framework for comparison. Journal of Foraminiferal Research, 10: 205-234. 
Seiglie, G.A., Baker, M.B., 1982. Foraminiferal zonation of the Cretaceous off Zaire and Cabinda, West Africa and its geological significance. AAPG Memoir, 34: 651-658.

Sen Gupta, B.K., Machain-Castillo, M.L., 1993. Benthic foraminifera in oxygen-poor habitats. Marine Micropaleontology, 20: 183-201.

Spezzaferri, S., 1994. Planktonic foraminiferal biostratigraphy and taxonomy of the Oligocene and lower Miocene in the oceanic record: an overview. Palaeontographia Italica, 81: 1-187.

Spezzaferri, S., 1995. Planktonic foraminiferal paleoclimatic implications across the Oligocene-Miocene transition in the oceanic record (Atlantic, Indian and South Pacific). Paleogeography, Palaeoclimatology, Palaeoecology, 114: 43-74.

Spezzaferri, S., Ćorić, S., 2001. Ecology of Karpatian (Early Miocene) foraminifera and calcareous nannoplankton from Laa an der Thaya, Lower Austria: a statistical approach. Geologica Carpathica, 200: 361-374.

Spezzaferri, S., Ćorić, S., Hohenegger, J., Rögl, F., 2002. Basin-scale paleobiogeography and paleoecology: an example from Karpatian (Latest-Burdigalian) benthic and planktonic foraminifera and calcareous nannofossils from the Central Paratethys. Geobios, Mémoire spécial, 24: 241-256.

Spezzaferri, S., Rögl, F., Ćorić, S., Hohenegger, J., 2004. Paleoenvironmental changes and agglutinated foraminifera across the Karpatian/Badenian (early/Middle Miocene) boundary in the Styrian Basin (Austria, Central Paratethys). Grzybowski Foundation Special Publication, 8: 423-459.

Şuraru, N., 1967. Beträge zur Kenntnis des Burdigals im nordwestlichen teil des Siebenbürger Beckens zwischen Cluj und Surduc (Rumänien). Neues Jahrbuch für Geologie und Paläontologie Monatshefte, (8): 489-497.
Tischler, M., Maţenco, L., Filipescu, S., Gröger, H.R., Wetzel, A., Fügenschuh, B., 2008. Tectonics and sedimentation during convergence of the ALCAPA and Tisza-Dacia continental blocks: the Pienide nappe emplacement and its foredeep (N. Romania). Geological Society Special Publications, 298: 317-334.

Tabără, D., Chirilă, G., 2012. Paleoclimatic estimation from Miocene of Romania, based on palynological data. Carpathian Journal of Earth and Environmental Sciences, 7: 195-208.

Ulleberg, K., 1974. Foraminifera and stratigraphy of the Viborg Formation in Sofienlund, Denmark. Bulletin of the Geological Society of Denmark, 23: 269-292.

Van der Zwaan, G.J., Jorissen, F.J., De Stigter, H.J., 1990. The depth dependency of planktonic/benthic foraminiferal ratios: constraints and applications. Marine Geology, 95: 1-16.

Van Hinsbergen, D.J.J., Kouwenhoven, T.J., Van der Zwaan, G.J., 2005. Paleobathymetry in the backstripping procedure: correction for oxygenation effects on depth estimates. Palaeogeography, Palaeoclimatology, Palaeoecology, 221: 245-265.

Van Houten, F.B., Puruker, M.E., 1984. Glauconitic peloids and chamositic ooids-favorable constraints and problems. Earth-Science Reviews, 20: 211-243.

Vasiliev, I., De Leeuw, A., Filipescu, S., Krijgsman, W., Kuiper, C., Stoica, M., Briceag, A., 2010. The age of the Sarmatian-Pannonian transition in the Transylvanian Basin (Central Paratethys). Palaeogeography, Palaeoclimatology, Palaeoecology, 297: 54-69.

Walton, W.R., Sloan, B.J., 1990. The genus Ammonia Brünnich, 1772: its geographic distribution and morphologic variability. Journal of Foraminiferal Research, 20: 128-156. 